\title{
PENGAMATAN PERTUMBUHAN DAN PRODUKSI TANAMAN BAWANG MERAH (Allium ascalonicum L.) VARIETAS LOKAL LEMBAH PALU PASCA APLIKASI BIOKOMPOS
}

\section{Observation of Growth and Production of Shallots (Allium ascalonicum L.) Local Variety of Palu Valley Post Biocompost Application}

\author{
Febiyanti $^{*}$ dan Umrah
}

Jurusan Biologi Fakultas MIPA, Universitas Tadulako, Palu JI. Soekarno-Hatta Km 9, Tondo Palu, Sulawesi Tengah 94117

\begin{abstract}
Keywords: Biocompos, Aspergillus sp, Red Onion

(Allium ascalonicum L.), Manure of chicken, goat, cattle, oyster mushrooms

Biocompost is an organic fertilizer term that is made from the process of decomposition of organic material through the addition of decomposers. This research has been carried out at the Botanical Gardens Department of Biology, Faculty of Mathematics and Natural Sciences, Tadulako University, Palu, from March to May 2019. The research waere aimed to determine the growth and production of shallot plants Allium ascalonicum L. and the appropriate dosage of biocompost to increase the growth and production of shallot plants of $A$. ascalonicum L. local varieties of the valley Hammer post biocompost application. The method used in this study is Complete Randomized Design method. The results of the observations can be concluded that biocompost made from livestock waste from goat chickens, cattle with oyster mushroom waste supplements made from active Aspergillus sp. Does not increase the growth and production of onion plants due to biocompost doses that are too high. Provision of 100 and 500 grams of biocompost / polybag has the lowest tuber dry weight.
\end{abstract}

Kata Kunci: Biokompos, Aspergillus $\mathrm{sp}$, Bawang Merah (Allium ascalonicum L.), limbah kotoran ternak ayam, sapi, kambing, jamur tiram.

\section{ABSTRAK}

Biokompos merupakan istilah pupuk organik yang dibuat dari proses dekomposisi bahan organik melalui penambahan dekomposer. Penelitian ini telah dilaksanakan di Kebun Botani Jurusan Biologi Fakultas Matematika dan Ilmu Pengetahuan Alam Universitas Tadulako Palu. Penelitian ini berlangsung pada bulan maret sampai mei 2019. Tujuan dari penelitian ini adalah untuk Mengetahui pertumbuhan dan produksi tanaman bawang merah Allium ascalonicum L. dandosis biokompos yang tepat untuk meningkatkan pertumbuhan dan produksi tanaman bawang merah $A$. ascalonicum L.varietas lokal lembah Palu pasca aplikasi biokompos. Metode yang digunakan pada penelitian ini yaitu menggunakan metode Rancangan Acak Lengkap. Hasil pengamatan dapat disimpulkan biokompos berbahan dasar limbah kotoran ternak ayam, kambing, sapi dengan suplemen limbah jamur tiram berbahan aktif Aspergillus $s p$. tidak meningkatkan pertumbuhan dan produksi tanaman bawang merah disebabkan dosis biokompos yang terlalu tinggi. Pemberian biokompos sebanyak 100 dan 500 gram/polybagmemiliki berat kering umbi terendah.

“Corresponding Author : febiyanti15i@gmail.com 


\section{PENDAHULUAN}

Bawang merah Allium ascalonicum L. merupakan salah satu komoditas utama sayuran di Indonesia yang mempunyai banyak manfaat. Bawang merah termasuk ke dalam kelompok rempah yang berfungsi sebagai bumbu penyedap makanan serta bahan obat tradisional.Berdasarkan data dari The National Nutrient Data Base bawang merah memiliki kandungan karbohidrat, gula, asam lemak, protein dan mineral lainnya yang dibutuhkan oleh tubuh manusia (Waluyo dan Sinaga, 2015).

Saat ini Indonesia sedang mengalami masalah pada distribusi bawang merah. Salah satu faktor penyebabnya adalah plot tanam yang hanya fokus pada beberapa daerah dan belum dikembangkannya daerah produksi baru. Produksi bawang merah tahun 2014 sebesar 1,234 juta ton. Hasil ini mengalami peningkatan sebesar 223,22 ribu ton atau $22,08 \%$ dibandingkan dengan tahun 2013dengan daerah penghasil tertinggi yaitu Jawa Tengah, Jawa Timur dan Jawa Barat. Peningkatan hasil produksi ini diperkirakan karena meningkatnya luas panen sebesar 21,77 ribu hektar atau 22,00\% (BPS, 2018).Potensi lahan pertanian di provinsi Sulawesi Tengah khususnya lembah Palu masih sangat luas untuk sayuran, termasuk bawang merah. Hal ini ditunjang dengan kondisi iklim yang keringdengan ketinggian 50 meter diatas permukaan laut dan jenis tanah latosol serta pengairan yang cukup (Putrasamedja dkk., 2004).

Salah satu faktor yang dapat mempengaruhi produksi bawang merah yaitu kondisi tanah yang kekurangan unsur hara akibat dari penggunaan tanah yang

dilakukan secara terus menerus oleh petani. Kondisi tanah yang seperti ini dapat mengurangi tingkat kesuburan serta menghambat pertumbuhan tanaman. Untuk mengatasi hal tersebut, dapat dilakukan dengan memanfaatkan penggunaan bahan organik seperti kompos dapat menambah ketersediaan unsur hara di dalam tanah. Kompos juga dapat memperbaiki sifat fisik tanah, sehingga tanah menjadi remah dan mikroba-mikroba tanah yang bermanfaat dapat hidup lebih subur. Kompos akan meningkatkan kesuburan tanah dan merangsang perakaran yang sehat. Kompos memperbaiki struktur tanah dengan meningkatkan kandungan bahan organik tanah dan meningkatkan kemampuan tanah untuk mempertahankan kandungan air tanah (Notodarmojo, 2005).

Di area pertanian lembah Palu Sulawesi Tengah yang beriklim kering terdapat jenis bawang merah yang beradaptasi dan dapat tumbuh serta berproduksi dengan baik. Jenis bawang merah ini dikenal dengan nama bawang merah varietas lembah Palu dan sudah diolah menjadi produk olahan siap saji yang biasa disebut "Bawang Goreng Palu" yang memiliki 
tekstur yang padat, gurih serta memiliki aroma yang khas, sehingga banyak disenangi oleh masyarakat (Ette dan Alam, 2009).

Manfaat bawang merah umumnya digunakan sebagai bahan bumbu dapur sehari-hari dan sebagai penyedap masakan. Bawang merah juga berkhasiat sebagai obat tradisional. Nenek moyang menggunakan umbi bawang merah sebagai obat nyeri perut karena masuk angin dan penyembuhan luka atau infeksi. Umbi bawang merah sebagai obat karena mempunyai efek antiseptik dari senyawa allin atau allisin. Senyawa allin ataupun allisin oleh enzim allisin liase diubah menjadi asam piruvat, ammonia dan allisin anti mikroba yang bersifat bakterisida. Bagian lain dari tanaman bawang merah seperti daun dan tangkai bunga bawang merah termasuk makanan yang lezat. Mengkonsumsi sayuran tersebut dapat membantu pencernaan, memperbanyak air ludah, menyembuhkan penyakit kuning, memperkuat hati dan membantu penyembuhan wasir (Rukmana, 1995).

Menurut Yuniwati, dkk (2012), biokompos memiliki manfaat yang dapat menyediakan unsur hara mikro dan makro bagi tanaman, menggemburkan tanah, memperbaiki struktur dan tekstur tanah, meningkatkan porositas, aerasi dan komposisi mikroorganisme tanah, dapat meningkatkan daya ikat tanah terhadap air, memudahkan pertumbuhan akar tanaman, dapat menyimpan air tanah lebih lama dan meningkatkan efisiensi pemakaian pupuk kimia.

Kotoran ayam memiliki kandungan $\mathrm{N}$ yang cukup tinggi, dibandingkan pupuk kandang hewan lainnya dan perbandingan $\mathrm{C} / \mathrm{N}$ rasio yang rendah. Kandungan $\mathrm{N}$ yang relatif tinggi pada kotoran ayam dapat dimanfaatkan untuk memenuhi kebutuhan hara pada tumbuhan. Selain itu penambahan pupuk padat kotoran ayam juga mampu memperbaiki sifat fisik tanah. Walaupun demikian pupuk padat kotoran ayam umumnya lebih lambat tersedia bagi tanaman, kerana membutuhkan waktu untuk proses dekomposisi (Hardjowigwno, 2007).

Pupuk kandang didevinisikan sebagai semua produk buangan dari hewan peliharaan yang dapat digunakan untuk menambah hara, memperbaiki sifat fisik dan biologi tanah. Hara dalam pupuk kandang tidak mudah tersedia bagi tanaman. Ketersediaan hara sangat dipengaruhi tingkat dekomposisi dari bahan-bahan tersebut. Rendahnya ketersediaan unsur hara lain disebabkan karena bentuk $\mathrm{N}, \mathrm{P}$ serta unsur lain terdapat dalam bentuk senyawa komplek protein atau asam humat atau lignin yang sulit terdekomposisi dari bahan bahan tersebut. Beberapa hasil penelitian aplikasi pupuk kandang kotoran ayam selalu memberikan respon yang terbaik. Hal ini terjasi karena kotoran ayam lebih cepat terdekomposisi serta mempunyai kadar hara yang cukup pula jika dibandingkan dengan jumlah unit yang 
sama dengan pupuk kandang lainnya (Hardjowigwno, 2007).

Menurut Cahaya dan Nugroho (2009), Kandungan pada kotoran kambing dapat digunakan sebagai bahan pembuatan kompos karena Kotoran kambing mengandung nilai rasio $\mathrm{C} / \mathrm{N}$ sebesar 21,12. Selain itu, kadar hara kotoran kambing mengandung $\mathrm{N}$ sebesar $1,41 \%$, kandungan $\mathrm{P}$ sebesar 0,54\%, dan kandungan $\mathrm{K} \quad$ sebesar $0,75 \%$. Penambahan kotoran kambing merupakan faktor yang harus diperhatikan dalam pembuatan biokompos.

Baglog jamur tiram dibuat dari pencampuran serbuk kayu gergaji dengan dedak, kapur dan gips (Susilowati dan Raharjo, 2004). Baglog jamur yang tidak terpakai lagi akan dibuang sehingga menimbulkan limbah. Limbah media tanam jamur tiram adalah bahan yang berasal dari media tanam jamur tiram setelah dipanen. Limbah baglog jamur tiram dapat dijadikan pupuk biokompos EM4 dan bahan organik lain maka sudah bisa dimanfaatkan sebagai pupuk yang baik untuk tanaman.

Jamur Aspergillus sp. merupakan fungi yang dapat diisolasi dari tanah berperanan sebagai dekomposer bahan organik menjadi biokompos atau humus (Rao, 1994). Limbah organik banyak terdapat di lingkungan dapat terdekomposisi secara alami oleh mikroorganisme yang yang bersifat saprofit asal tanah. Pada umumnya mikroorganisme dekomposer, termasuk mikroba asal tanah, seperti
Aspergillus sp. dan Trichoderma sp. kedua mikroba tersebut berpotensi untuk dikembangkan sebagai mikroba decomposer yang berperanan dalam proses pengomposan, baik secara alami maupun melalui eksperimen.

\section{BAHAN DAN METODE}

Bahan yang digunakan yaitu bawang merah varietas lembah Palu, biokompos, tanah, air, label dan sekam padi dan abu. Alat yang digunakan dalam penelitian ini adalah polybag, timbangan analitik, kamera, oven, dan mistar.

\section{Rancangan Penelitian}

Penelitian ini menggunakan rancangan acak lengkap (RAL) terdiri dari tujuh perlakuan dan 4 kali ulangan. Susunan perlakuan sebagai berikut:

K0: tanpa aplikasi biokompos (300 ml air) K1:aplikasi biokompos 100 gram/polybag K2:aplikasi biokompos 200 gram/polybag K3:aplikasi biokompos 300 gram/polybag K4:aplikasi biokompos 400 gram/polybag K5:aplikasi biokompos 500 gram/polybag K6:aplikasi biokompos 600 gram/polybag Komposisi biokompos terdiri dari kotoran ternak dengan perbandingan 1:1:1ayam 23,3 kg, kambing 23,3 kg, sapi $23.3 \mathrm{~kg}$, Aspergillus sp $1 \mathrm{~kg}$ dan jamur tiram $30 \mathrm{~kg}$.

\section{Pemilihan benih}

Benih yang digunakan dalam penelitian ini adalah benih bawang merah Allium ascalonicum L.variates lembah Palu yang tidak memiliki cacat dan berukuran seragam bebas dari hama dan penyakit, kriteria pemilihan benih yaitu ukuran bawang merah sedang, warna merah 
mengkilap, tidak memiliki cacat, bagus dan sempurna, dan benihnya telah tersimpan 2-3 bulan.

\section{Persamaian benih bawang merah varites lembah Palu}

Benih yang sudah dipilih disemaikan menggunakan polybag yang sudah disiapakan lalu ditanam benihnya, setelah 11 hari persemain ditimbang, kemudian diseleksi bibit berdasarkan kualitas tumbuh dari benih bawang merah yang telah disemaikan.

\section{Penyiapan media tanah}

Media yang digunakan adalah tanah sebanyak $4.750 \mathrm{~g}$, sekam padi dan abu sebanyak 250 g,tanahnya diayak kemudian dicampurkan dengan sekam padi dan abu dan dimasukan kedalam setiap polybag. Sekam padi berfungsi memperbaiki struktur tanah dan meningkatkan porositas tanah.

\section{Penanaman}

Benih bawang merah yang akan ditanam disemaikan terlebih dahulu selama 1 minggu. Benih yang ditanam sebanyak 1 benih dalam 1 polybag penanaman tepat dilakukan ditengah media tanam dan dilakukan pada pagi hari

\section{Aplikasi biokompos}

Pemberian biokompos diberikan sebanyak 2 kali yaitu sebelum penanaman benih dan sebulan setelah tanam yang diberikan secara berturut- turut yaitu $\mathrm{KO}$ tanpa aplikasi biokompos (kontrol), K1 biokompos 100 gram, K2 biokompos 200 gram, K3 biokompos 300 gram, K4 biokompos 400 gram, K5 biokompos 500 gram, K6 biokompos 600 gram.

\section{Pemeliharaan tanaman}

Penyiangan dilakukan untuk membersihkan rumput-rumput liar dan gulma lainnya yang tumbuh di area polybag dengan cara mencabut mengunakan tangan.

Penyiraman setiap dua kali sehari

Penyiraman dilakukan setiap dua kali sehari pada sore hari atau sesuai dengan keadaan cuaca.

Pengemburan tanah.

Pengemburan tanah dilakukan jika tanah sudah mulai padat hal ini bertujuan untuk membuat unsur hara yang mengendap dibawah menjadi keatas dan air mudah masuk kedalam tanah dan mudah menyerap air.

\section{Pemanenan}

Pemanenan dilakukan setela bawang merah berumur 60 hari.Kriteria pemanenan sudah mulai berjatuhan tanamannya, daunnya mulai mongering, berwarna kuning pucat, pangkal batang lemas, teksturnya keras dan menimbulkan aroma yang khas dari bawang merah.

\section{Tahap pengamatan}

a. Tinggi tanaman $(\mathrm{cm})$

Pengukuran dilakukan setiap 3 hari, dari pangkal daun sampai ujungdaun yang terpanjang, pada umur 3 , $6,9,12,15,18,21,24,27,30,33,36,39$, sampa i 60 hari. Pengukuran dilakukan dengan menggunakan mistar.

b. Jumlah daun 
Dihitung daun setiap 3 hari, selama pertumbuhan jumlah daun yang terbentuk sempurnah pada umur $3,6,9,12,15,18,21,24,27,30,33,36,39$, sampai 60 hari.

c. Jumlah umbi Jumlah umbi dihitung setelah pasca panen bawang merah.

d. Berat biomassa

Berat biomassa ditimbang untuk pemelihan benih.

e. Berat biomassa pasca panen

Berat biomassa ditimbang saat pasca panen, bawang yang masi utuh yang belum dipisahkan tajuk, umbi dan akarnya. f. Berat segar

Berat segar umbi, tajuk dan akar ditimbang dalam keadaan segar, dilakukan pada akhir pengamatan.

g. Berat kering

Berat kering umbi, tajuk dan akar yang telah ditimbang selanjutnnya dikeringkan selama 60 jam didalam oven dengan suhu $70{ }^{\circ} \mathrm{C}$, kemudian ditimbang kembali berat keringnya.

\section{ANALISIS DATA}

Data hasil pengamatan secara kuantitatif dilakukan analisis ragam one wayanova dengan menggunakan program software SPSS, bila mana terjadi perbedaan terhadap masing-masing perlakuan dilanjutkan dengan uji Duncan pada taraf $5 \%$.

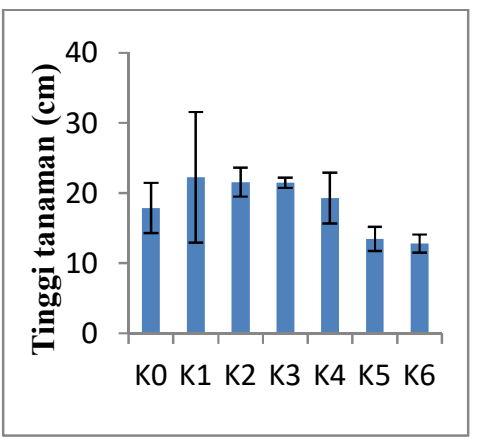

Gambar 1.Tinggi tanaman

Gambar 1 menujukan nilai rata-rata perkembangan tinggi tanaman bawang merah $A$. ascalonicum $L$. dari hari awal (0) pengamatan hingga hari ke-60. Perlakuan (K1) menujukan perkembangan paling tinggi pada hari ke-60 yaitu $22,25 \mathrm{~cm}$.

\section{Jumlah Daun (helai)}


Hasil pengamatan dari analisis ragam menujukan bahwa pemberian biokompos tidak berbeda nyata pada jumlah daun bawang merah $A$. ascalonicum L.dan rata - rata jumlah daun dengan perlakuan yang berbeda dapat dilihat pada gambar 2 .

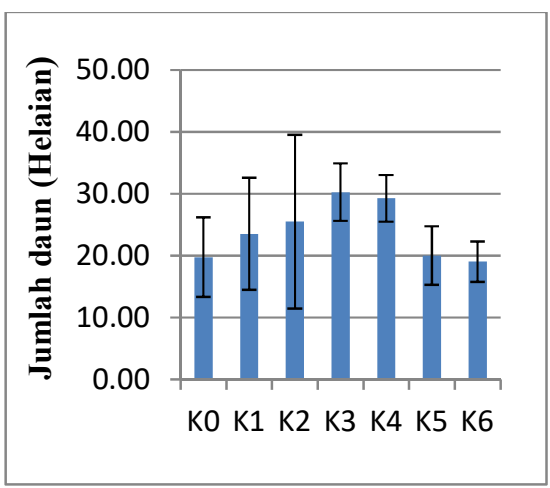

Gambar 2. Jumlah daun (helai)

Gambar 2 menujukan nilai rata-rata perkembangan jumlah daun tanaman bawang merah $A$. ascalonicum $L$ dari hari awal (0) pengamatan hingga hari ke-60. Perlakuan (K3) menujukan perkembangan paling tnggi pada hari ke-60 yaitu 30,25 $\mathrm{cm}$. dan perkembangan jumlah daun terendah terdapat pada perlakuan $\mathrm{K} 6$ dengan rata-rata tinggi tanaman yaitu $19.00 \mathrm{~cm}$.

\section{Jumlah Umbi}

Hasil pengamatan dari analisis ragam menujukan bahwa pemberian biokompos berpengaruh nyata pada jumlah umbi bawang merah $A$. ascalonicum $\mathrm{L}$. dan rata- rata jumlah umbi dengan perlakuan yang berbeda dapat dilihat pada gambar 3.

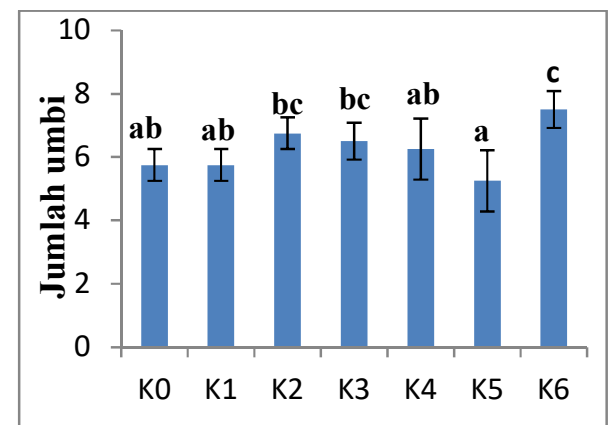

Gambar 3. Jumlah umbi

Nilai rata-rata tanaman bawang merah $A$. ascalonicum L. tertinggi pada perlakuan K6 $(7,50)$ disusul perlakuan K2 $(6,75)$, K3 $(6,50)$, K4 $(6,25)$, K0 $(5,75)$ K1 $(5,75)$ dan terendah pada perlakuan $\mathrm{K} 5$ $(5,25)$.Kandungan unsure $N$ yang tinggi membuat tanaman lebih hijau sehingga proses fotosintesis dapat berjalan sempurns yang berpengaruh terhadap kualitas dan kuantitas akhir panen dengan kandungan unsur $\mathrm{N}$ yang lebih banyak maka akan meransang tumbuhnya anakan sehingga akan diperoleh hasil panen dengan jumlah umbi yang lebih banyak karena faktor anakan berpengaruh dengan jumlah umbi. Kalium (K) ialah salah satu unsur hara makro yang penting bagi pertumbuhan danperkembangan tanaman.Kalium mempunyai peran sebagai activator beberpa enzim dan metabolism tanaman .Pada bawang merah kalium dapat memberikan hasil umbi yang lebih banyak,mutu dan daya simpan umbi yang lebih tinggi, dan umbi tetap padat meskipun disimpan lama (Gunandi, 2009). 


\section{Berat Biomassa dan Biomasaa Pasca Panen (g)}

Hasil pengamatan berat biomassa bawang merah $A$. ascalonicum $L$. tidak berbeda nyata pada setiap perlakuan, nilai rata-rata tertinggi pada perlakuan $\mathrm{K} 6$ $(3,31)$ disusul K3(2.72), K1 (2,55), K0 $(2,51), \mathrm{K} 4(2,47), \mathrm{K} 2$ (2.29), dan rata-rata nilai terendah pada perlakuan K5 (2.18) dapat dilihat pada gambar 4 .

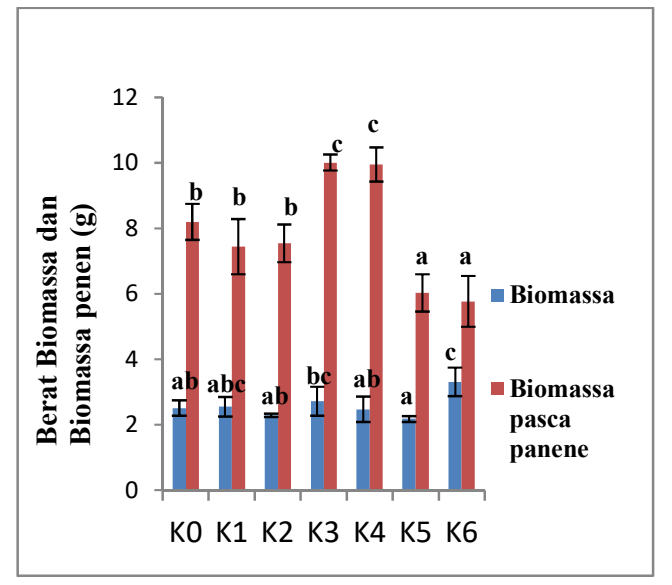

Gambar 4. Berat biomassa dan biomassa pasca penen

Pemberian biokompos berpengaruh nyata terhadap berat segar tajuk bawang merah A. ascalonicum L. Nilai rata-rata tertinggi pada perlakuan K3 $(10,01)$ disusul K4 $(9,95)$, K0 $(8,20)$, K2 $(7,54)$, K1 $(7,44)$, K5 $(6,03)$ dan rata-rata nilai terendah pada perlakuan K6 (5.77) dapat dilihat pada gambar 4.4.Berat biomassa tanaman sangat erat kaitannya dengan organ yang ada pada tanaman yaiutu daun,pada daun terjadi proses fotosintesis, hasil fotosistesis kemudian terakumulasi menjadi berat kering tanaman bawang merah. Pertumbuhan daun yang semakin baik maka semakin besar pula berat ISSN-P : 1978-6417; ISSN-E : 2580-5991 kering tanaman tersebut. Bila tanaman mendapatkan unsure $\mathrm{N}$ yang cukup maka daun akan tumbuh besar dan memperluas permukaannya. Permukaan daun yang luas tersebut dapat memungkinkan cahaya matahari diserap lebih banyak sehingga proses fotosintesis berlangsung lebih cepat sahingga fotosintat yang berbentuk akan terakumulasi pada bobot kering tanaman (Amir dkk., 2012).

\section{Berat Segar dan Kering Tajuk (g)}

Pemberian biokompos berpengaruh nyata terhadap berat segar tajuk bawang merah A. ascalonicum L. Pada setiap perlakuan nilai rata- rata tertinggi pada perlakuan $\mathrm{K} 3$ $(4,15)$ disusul K4 $(3,45)$, K6 $(2,79)$, K0 $(1.97), \mathrm{K} 2(1,89) \mathrm{K} 5(1,83)$ dan nilai ratarata terendah pada perlakuan K1 $(1,20)$ dapat dilihat pada gambar 6 .

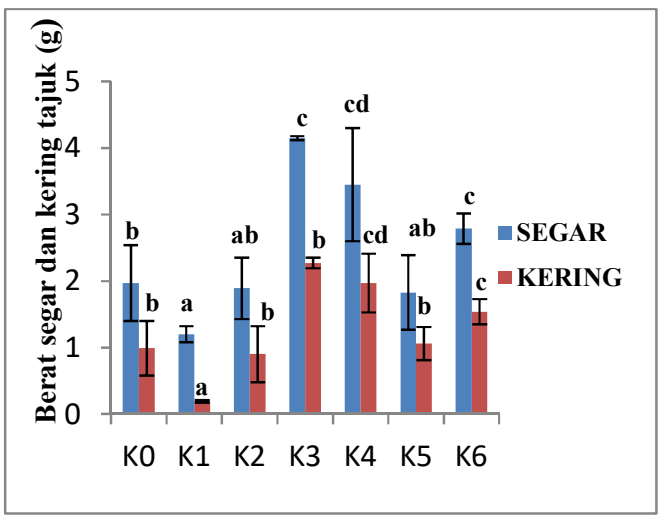

Gambar 5. Berat segar dan kering tajuk

Pemberian biokompos berpengaruh nyata terhadap berat kering tajuk bawang merah A. ascalonicum L. Berpengaruh nyata pada setiap perlakuan, nilai rata- rata tertinggi pada perlakuan K3 $(2,27)$ disusul K4 $(1,97)$ K6 $(1,54)$ K5 $(1,06)$ K0 $(0,99)$ K2 $(0,90)$ dan nilai rata-rata terendah pada 
perlakuan K1 $(0,19)$ dapat dilihat pada Gambar 4.5.Darwin (2012) menyatakan komoditas sayuran jumlah daun akan berpengaruh terhadap bobot berat segar tajuk dan berat kering tajuk .Semakin banyak jumlah daun maka akan menunjukan bobot berat segar tajuk dan kering tajuk yang tinggi. Berat segar dan berat kering tajuk meliputi batang dan daun yang berarti akumulasi dari hasil fotosintesis dan dipengaruhi ketersediaan unsur hara. Bobot segar tajuk dan bobot kering tajuk merupakan gambaran dari fotosintesis selama tanaman melakukan proses pertembuhan.

\section{Berat Segar dan Kering Umbi (g)}

Pemberian biokompos berpengaruh nyata terhadap berat segar umbi bawang merah $A$. ascalonicum $\mathrm{L}$. pada setiap perlakuan nilai rata- rata tertinggi pada perlakuan $\mathrm{K} 4$ $(3,50)$ disusul K3 $(3,32)$ K0 $(2,88)$ K6 $(2,42) \mathrm{K} 2(2,35), \mathrm{K} 5(2,29)$, dan nilai ratarata terendah pada perlakuan K1 $(1,99)$ dapat dilihat pada gambar 6 .

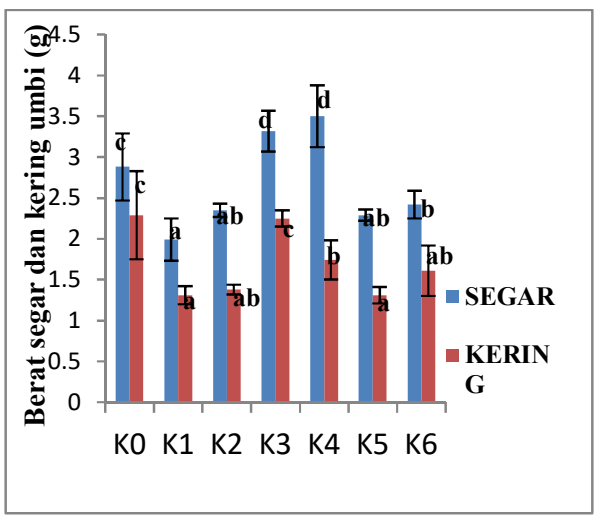

Gambar 6. Berat segar dan kering umbi

Pemberian biokompos berpengaruh nyata terhadap berat kering umbi bawang merah ISSN-P : 1978-6417; ISSN-E : 2580-5991
A. ascalonicum $\mathrm{L}$. Nilai rata- rata tertinggi pada perlakuan KO $(2,29)$ disusul K3 $(2,25), \mathrm{K} 4(1,74), \mathrm{K} 6(1,61) \mathrm{K} 2(1,38)$, dan nilai rata-rata terendah pada perlakuan $\mathrm{K} 1$ dan K5 (1.31) dapat dilihat pada Gambar 6. Pengamatan terhadap berat segar umbi tanaman bawang merah $A$. ascalonicum $\mathrm{L}$. dengan pengaplikasian biokompos memberikan pengaruh nyata bagi tanaman nilai rata-rata tertinggi berat segar umbi pada perlakuan K4 $(3,50)$ dengan dosis biokompos 400 gram/polybag. Sedangkan berat kering umbi tidak dipengaruhi oleh pemberian biokompos.Dosis biokompos juga tidak memberikan pengaruh terhadap berat kering bawang merah.Tanaman bawang merah yang diberi biokompos dengan dosis 100 dan 500 gram/polybag cenderung memiliki berat kering tajuk terendah. Hal ini disebabkan bahwa pupuk kandang yang diberikan tidak sesuai atau tidak seimbang dengan kebutuhan tanaman bawang merah. Menurut Parnata (2004) yang menyatakanuntuk memenuhi kebutuhan tanaman kita harus bisa menyediakan unsur hara dalam jumlah yang dipekirakan cukup dan seimbang. Tanaman dapat tumbuh dengan baik dan menghasilkan hasil yang tinggi diperlukan unsur hara yang cukup dan seimbang (Anonymous,2005).

\section{Berat Segar dan Kering Akar (g)}

Pemberian biokompos berpengaruh nyata terhadap berat segar akar bawang merah A. ascalonicum L. pada setiap perlakuan nilai rata- rata tertinggi pada perlakuan $\mathrm{K} 3$ 
$(1,38)$ disusul K4 $(1,17)$, K5 $(0,74)$, K2 $(0,67), \mathrm{K} 1(0,64), \mathrm{K} 6(0,58)$, dan nilai ratarata terendah pada perlakuan $\mathrm{K} 0(0,49)$ dapat dilihat pada gambar 7 .

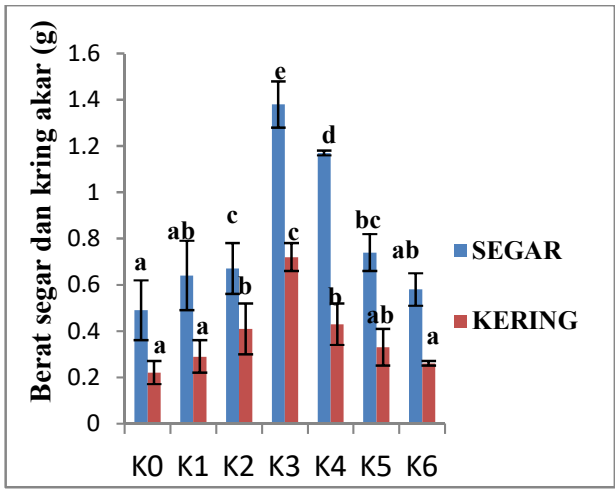

Gambar 7. Berat segar dan kering akar.

Pemberian biokompos berpengaruh nyata terhadap berat kering akar bawang merah A. ascalonicum L. Nilai rata- rata tertinggi pada perlakuan $\mathrm{K} 3(0,72)$ disusul $\mathrm{K} 4$ $(0,43), \mathrm{K} 2(0,41), \mathrm{K} 5(0,33), \mathrm{K} 1(0,29), \mathrm{K} 6$ $(0,26)$, dan nilai rata-rata terendah pada perlakuan K0 $(0,22)$ dapat dilihat pada Gambar 7. Hapiza dkk., (2014) menyatakan bahwa adanya nitrogen yang cukup akan mempercepat laju pertumbuhan dan pemanjangan akar batang dan daun,unsur hara yang telah diserap oleh akar membeikan kontribusi terhadap penambahan berat segar akar dan berat kering akar. Ketersediaan unsure $P$ yang cukup dalam tanah sangat penting untuk meningkatkan pertumbuhan tanaman $\mathrm{P}$ diperlukan untuk perbaikan kandungan karbohidrat dan perkembangan akar tanaman (Fitri dkk., 2014).

Pada penelitian ini tanaman dengan tanpa pemberian biokompos (K0) cenderung ISSN-P : 1978-6417; ISSN-E : 2580-5991 tumbuh lebih baik dibandingkan dengan tanaman yang diberikan biokompos dengan melihat parameter dari berat kering umbi yang diukur. Tanaman bawang yang diberi biokompos dengan dosis 100 dan 500 gram/polybag cenderung memiliki berat kering umbi terendah. Kurangnya pengaruh biokompos pada penelitian ini mungkin disebabkan salah satunya oleh kelebihan unsur hara P. Fosfor merupakan unsur hara makro esensial yang dibutuhkan tanaman untuk pembentukan sel pada jaringan akar dan tunas yang sedang tumbuh serta memperkuat batang (Aleel, 2008). Semakin tinggi dosis biokompos yang diberikan pertumbuhan tanaman cenderung semakin rendah. Hal ini menunjukkan bahwa dosis pupuk yang diberikan melebihi dosis optimal yang diperlukan untuk pertumbuhan tanaman bawang merah. Kebutuhan unsur hara pada tanaman bawah merah cenderung lebih rendah dari tanaman lain seperti jagung.

Menurut Sumarni dkk. (2012) dosis pupuk P 92-126 kg/ha merupakan dosis optimal untuk pertumbuhan tanaman bawang merah. Sedangkan pada tanaman jagung dosis optimal pupuk $P$ yaitu $150-240 \mathrm{~kg} / \mathrm{ha}$ (Herlina dkk, 2018). Dosis optimal pupuk $P$ pada tanaman jagung lebih tinggi dibandingkan dengan dosis optimal pupuk $\mathrm{P}$ pada tanaman bawang merah. Akan tetapi kandungan unsur hara tanah pada penelitian ini tidak dilakukan pengukuran. 


\section{KESIMPULAN}

Pemberian biokompos tidak meningkatkan pertumbuhan dan produksi tanaman bawang merah disebabkan dosis biokompos yang terlalu tinggi. Pemberian biokompos sebanyak 100 dan 500 gram/polybagmemiliki berat kering umbi terendah.

\section{DAFTAR PUSTAKA}

\section{Anonymous, 2005. Dalam Upaya Pemberdayaan Masyarakat Disekitarnya: Petrokimia Gresik.}

Aleel, K.G. 2008. Phosphate Accumulation in Plant:Signaling. Plant Physiol, 148, 3-5.

Amir, L., Sari, A.P., Hiola, St. F dan Jumadi, O. 2012.Ketersediaan nitrogen tanah dan pertumbuhan tanaman bayam (Amarantus tricolor L.) yang diperlukan dengan pemberian pupuk kompos azolla.Jurnal Sainsmartl(2), 167180.

Cahaya,A.,T. dan Nugroho D.A. 2009. Pembuatan Kompos dengan Menggunakan Limbah Padat Organik (Sampah Sayuran dan Ampas Tebu).Skripsi. Fakultas Teknik Kimia Universitas Diponegoro. Semerang.

Darwin, H.P. 2012. Pengaruh pupuk organic cair terhadap pertumbuhan dan produksi sayuran daun kangkung , bayam dan caisin. Proseding Sememinar NasiomalPerhimpunan Hortikultural Indonesia. (pp.154-160).

Ette, A. dan Alam, 2009. Karakteristik Mutu Bawang Goreng Palu Sebelum Penyimpanan. Jurnal Agroland16(4), 273-280.
Fitri, A., Rosita,s., dan Chairani, H. 2014. Pertumbuhan dan produksi bawang merah dengan pemberian berbagai pupuk organic.Jurnal Agreoteknologi2(2), 482-496.

Gunadi, N. 2009. Kalium sulfat dan kalium klorida sebagai sumber pupuk kalium pada tanaman bawang merah. Jurnal Hort 19(2), 174-85.

Hardjowigeno, S. H. 2007. Ilmu tanah. Jakarta: Akademika Pressindo.

Herlina, M.P., Yunus, A., Harjoko, D. 2018. Dosis Pupuk Fosfat Terhadap Pertumbuhan dan Hasil Beberapa Jagung Hibrida. Jurnal Agrosains 20(2), 34-39.

Notodarmojo, S. 2005. Pencemaran Tanah dan Air Tanah. Bandung: ITB press.

Putrasamedja, S., Suryadi, dan Maskar. 2004. Evaluasi Pertumbuhan Dan Daya Hasil Enam Klon Bawang Merah Di Dataran Rendah Donggala.JurnalPembangunan Pedesaan 4(3), 157-158.

Pranata, Ayub. S. 2004. Pupuk Organik Cair Aplikasi dan Manfaatnya Jakarta:

Agmedia Pustaka.

Rao, S. 1994. Mikroorganisme Tanah dan Pertumbuhan Tanaman.Edisi Ke-2. Jakarta: UI Press.

Rukmana, R.1995. Bawang merah budidaya dan pengolahan pasca panen.Yogyakarta: Kanisius.

Rukmana, R. 1997. Usaha tanaman jagung.Yogyakarta: Kanisius.

Susilawati dan Raharjo, B. 2004. Budidaya Jamur Tiram Pleourotus ostreatus var floridayang ramah lingkungan. Palembang: BPTP Sumatera Selatan. 
Sumarni, N., Rosliani, R., Basuki, RS., Hilman, Y. (2012). Respons Tanaman Bawang Merah Terhadap Pemupukan Fosfat pada Beberapa Tingkat Kesuburan Lahan (Status PTanah). Jurnal Hort 22(2), 129-137.

Waluyo, N. dan Sinaga, R. 2015. Bawang Merah yang di Rilis oleh Balai Penelitian Sayuran. Diperoleh dari s itus website: hhtp://www.balitsa.litban g.deptan.go.id

Yuniwati, M., Iskarima, F., dan Padulemba, A. 2012. Optimasi Kondisi Proses Pembuatan Kompos Dari Sampah Organik Dengan Cara Fermentasi Menggunakan Em4. Jurnal Teknologi5(2), 172-181. 